
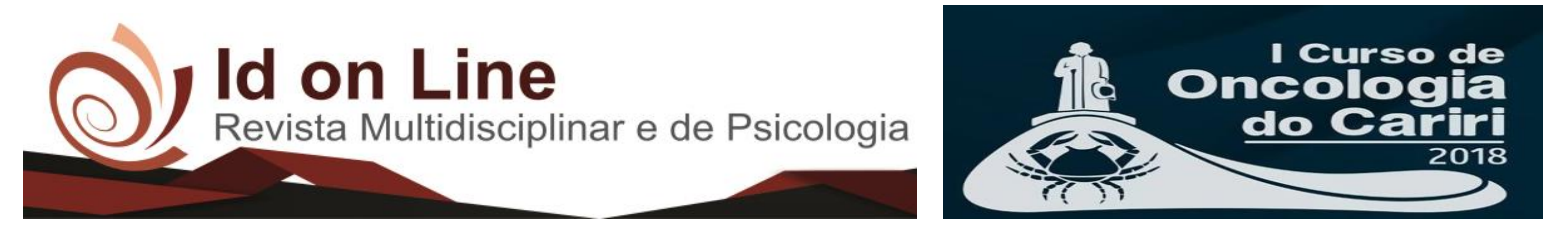

Editorial

\title{
QUALIDADE DE VIDA E DIGNIDADE AOS PORTADORES DE CÂNCER
}

Gislene Farias de Oliveira ${ }^{1}$

Sempre pensamos na vida humana como um bem extremamente precioso, de valor inestimável. A vida é o que nos permite os sonhos e realizações humanas. E é através da saúde, que mantemos sua total plenitude.

As doenças, por sua vez, tiram o equilíbrio do corpo, ameaçam a vida e, consequentemente nossas possibilidades. O câncer é algo devastador para o ser humano. Não apenas para o enfermo, mas também para seus familiares. Perde-se o sentido da vida, perde-se a sensação de plenitude. Desejos e realizações antes tão valorizados, são abandonados.

A associação câncer-morte ainda é um estigma, que aos poucos vem sendo abandonado nas práticas em saúde e, na própria medicina em si.

Muitos são os avanços técnico-científicos na contemporaneidade, que favorecem o paciente oncológico, trazendo mais esperança sobre a possibilidade de cura.

Neste contexto, o I Curso de Oncologia do Cariri e II Jornada de Pesquisa Quantiqualitativa em Oncologia, promovidos pela Liga Acadêmica de Oncologia (LAON) da Faculdade de Medicina Estácio de Juazeiro do Norte - CE, abrem espaço para maiores discussões sobre a temática, além de refletirem, através de trabalhos científicos, sobre a qualidade de vida e sobre a dignidade dos portadores de câncer.

Trata-se de um árduo caminho que sinaliza com grandes resultados. Os acadêmicos de medicina farão parte de um corpo de cuidadores, que certamente utilizarão novos conceitos sobre a vida e sobre a morte, bem como sobre uma esperança nunca abandonada, visando uma constante superação. Que este seja o constante objetivo que molde suas práticas cotidianas e promova seu crescimento pessoal e profissional.

Aos profissionais oncológicos, cabe essencialmente, não apenas a tarefa de paliar mas, de prevenir e promover as condições necessárias a manutenção e garantia da dignidade do ser humano.

51 Id on Line Rev. Mult. Psic. V.12, N. 40. 2018 - ISSN 1981-1179

EDIÇÃO ESPECIAL: I CURSO DE ONCOLOGIA DO CARIRI / II JORNADA DE PESQUISA QUANTI-QUALITATIVA EM

ONCOLOGIA. JUAZEIRO DO NORTE, 05 A 10 DE MARÇO DE 2018.

Edição eletrônica em http://idonline.emnuvens.com.br/id 
Este evento é dedicado a todos os profissionais que incessantemente lutam pela vida, num constante superar-se, numa luta que ultrapassa suas reais possibilidades de compreensão.

Aos pacientes oncológicos, nosso sincero apreço, bem como nossa gratidão pela oportunidade de aprendizado, no acompanhamento de suas lutas, vitórias, momentos de fraqueza e, principalmente pela oportunidade de contribuir com suas histórias de vida.

${ }^{1}$ Doutorado em Psicologia Social pela Universidade Federal da Paraíba - UFPB e Pós doutorado em Ciências da Saúde pela Faculdade de Medicina do ABC, São Paulo. Docente da Faculdade de Medicina da Universidade Federal do Cariri - UFCA. Contato: gislene.farias@ufca.edu.br. 